\title{
LANDSCAPES, SETTLEMENTS AND TRADITIONAL HOUSING IN SAMTSKHE-JAVAKHETI, GEORGIA
}

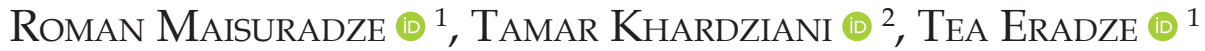 \\ ${ }^{1}$ Department of Geography, Ivane Javakhishvili Tbilisi State University, Tbilisi, Georgia \\ ${ }^{2}$ Vakhushti Bagrationi Institute of Geography, Ivane Javakhishvili Tbilisi State University, Tbilisi, Georgia
}

Manuscript received: February 4, 2021

Revised version: March 1, 2021

\begin{abstract}
Maisuradze R., Khardziani T., Eradze T., 2021. Landscapes, settlements and traditional housing in Samtskhe-Javakheti, Georgia. Quaestiones Geographicae 40(1), Bogucki Wydawnictwo Naukowe, Poznań, pp. 85-95. 5 figs, 2 tables.

AвSTRACT: A change in livelihood and folk architecture is an indicator of cultural landscape transformation, which is often the result of changes occurring in the natural and socio-political realms. The diversity of architectural types of buildings as an element of landscape diversity distinguishes our research region. The presented study deals with a long-term change of housing and architectural types of settlements. Our goal was to identify, geolocalise, and classify the vernacular architecture of Samtskhe-Javakheti within the different types of natural landscapes. For this purpose, we used the HGIS (Historical Geoinformation System) approach, which comprises the application of both historic sources and GIS technologies. We identified seven types of buildings in the study area, the characteristics of which depended on the natural landscape features. The following factors had been determining the geography of the construction: geology, seismicity, terrain, climate, access to building materials and defence. Dominant architectural types of buildings in the study region were as follows: fortress Rabat with stone houses, stone houses, semi-underground houses mixed with stone houses, semi-underground houses, terraced semi-underground houses, cave dwellings and wooden log houses. In modern times, it is quite rare to come across these kinds of architectural buildings, and there is a tendency of their disappearance.
\end{abstract}

KEY WORDs: landscape, settlement, traditional housing, historical GIS, Samtskhe-Javakheti, Georgia

Corresponding author: Tamar Khardziani, tamar.khardziani@tsu.ge

\section{Introduction}

A study of changes in the human environment and physical landscape is the subject of complex and interdisciplinary research. Traces of historical processes are often reflected in landscapes, formed over a long period of time (Braudel, Wallerstein 2009). The retrospective approach involves analyzing the objects and events of nature and society that existed in the past. This includes the preparation of historical geoinformation systems based on the existing historical data, which has been quite relevant in recent decades (Gregory, Healey 2007, Cirucci et al. 2015).

Vernacular architecture is an essential part of society's life, culture and tradition. From ancient times people have been trying to adapt to the environment and find a comfortable living space, where they could be protected from threats. In terms of cultural heritage conservation, it is essential to study and preserve the diversity of types of buildings within the landscape (Charter 
1931, 1964). The origin and development of folk architecture are related to centuries of local knowledge, which also implies adaptation to the local environment (Battaini-Dragoni 2008, Sangiorgi 2008, Braudel, Wallerstein 2009). Their variety is determined by the peculiarities of the local landscape, which is diverse in the study area (Maisuradze et al. 2018). Here, vernacular buildings are mostly characterised by a mixed age and are associated with the construction style of different periods. Some buildings were adapted to both, seismic activity (Vallerani 1995, Jibson 2011) and exodynamic processes of the area (Ilies, Moldovan 2014).

During the Soviet period, the appearance of traditional housing changed dramatically. Settlement types became more homogeneous, as similar architectural style buildings were built (Khoshtaria et al. 2019). This trend affected both urban and rural settlements. If we look at today's rural settlements, we find that since the second half of the twentieth century, almost identical houses have been built. Fewer people live in traditional Meskhetian houses or wooden houses (Ochiauri 1970). Their functional purpose has changed, and in many cases, they are being used for storing products and cattle shelters. Old buildings carry many interesting stories, histories, inscriptions, and artefacts, which are scattered among villages, settlements and individual buildings, so their preservation is of great cultural importance (Charter 1964, Sangiorgi 2008).

The paper presents the study of medieval settlements and types of traditional buildings in the Samtskhe-Javakheti region, as well as their geographical allocation and surrounding landscapes.

\section{Study area}

Samtskhe-Javakheti is located in the southern part of Georgia (Figs 1, 2) and includes six municipalities: Adigeni, Akhaltsikhe, Borjomi, Aspindza, Akhalkalaki and Ninotsminda. The region covers an area of $6412.8 \mathrm{~km}^{2}$ and has a population of 160,262 people. The following relief features can be seen in the area: volcanic highlands of southern Georgia, in the form of volcanic plateaus, canyons and Javakheti-Samsar-Erusheti ridges, Akhaltsikhe Valley and Lesser Caucasus mountain system, in the form of Arsiani and Adjara-Trialeti ridges. The highest peak is Didi Abuli (3301 $\mathrm{m}$ a.s.l.) on the Abul-Samsar ridge (Fig. 1).

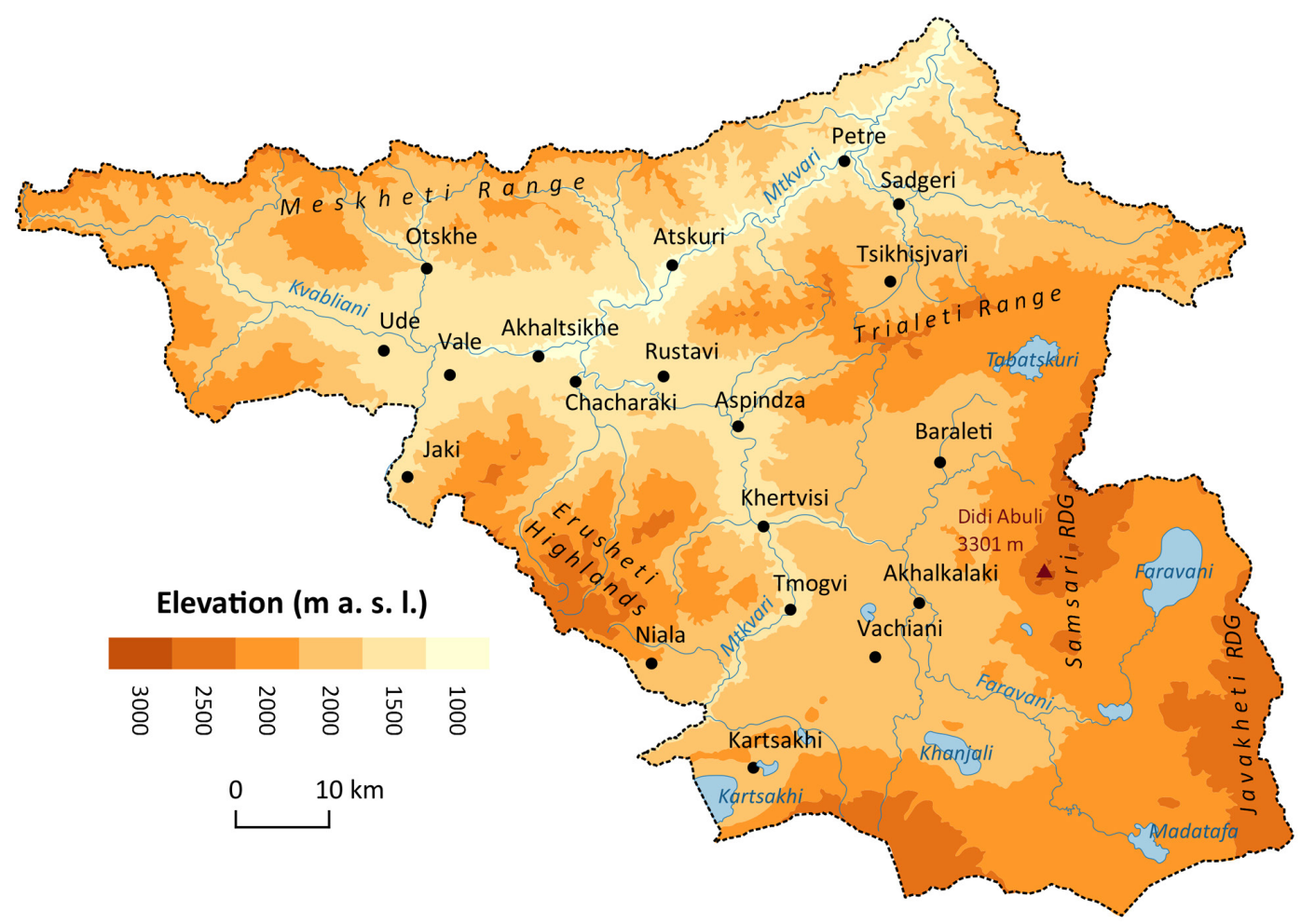

Fig. 1. Samtskhe-Javakheti relief. 


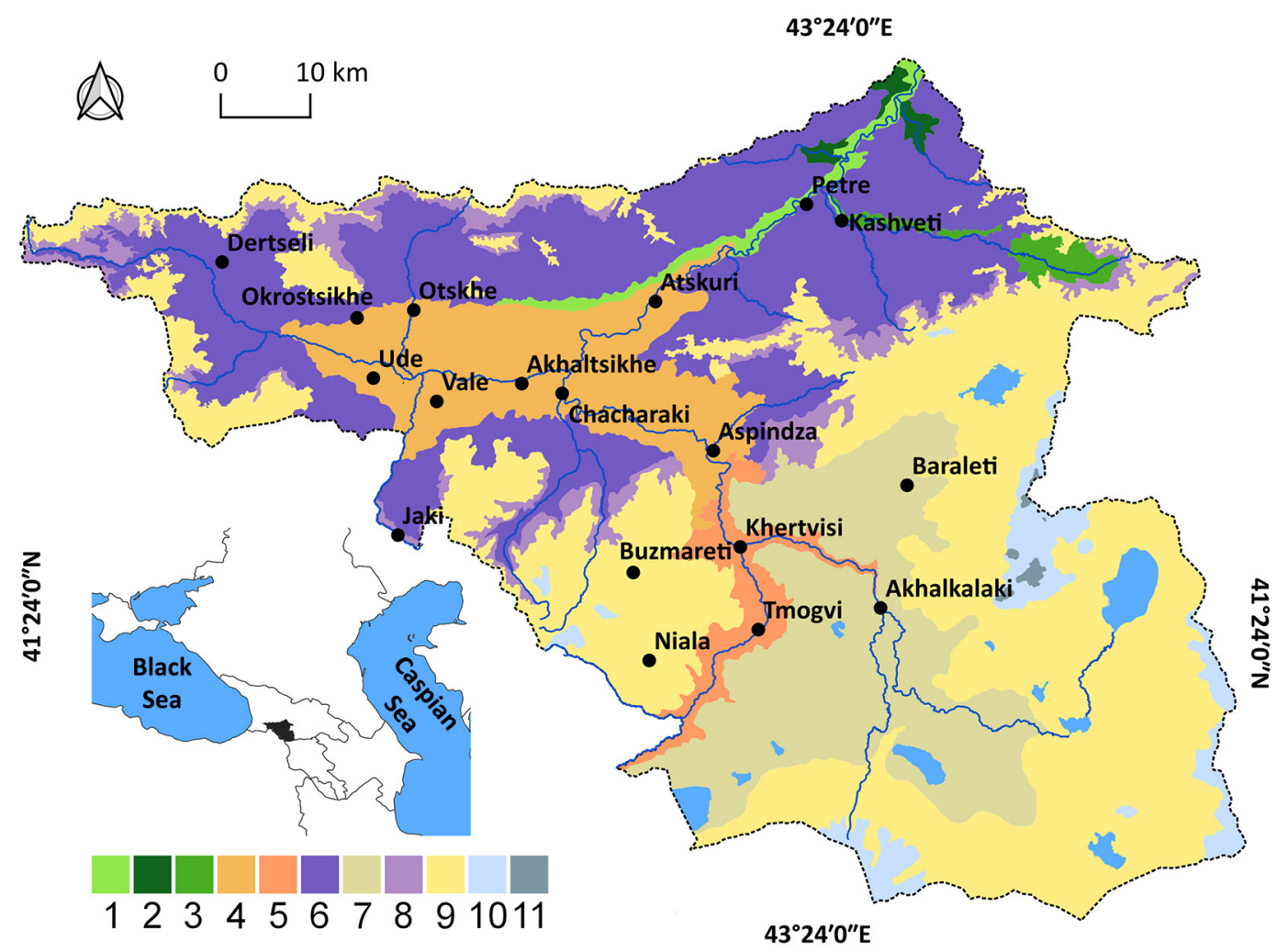

Fig. 2. Location of the study area and its landscapes.

1 - lower mountain semi-humid forest, 2 - middle mountain Colchian forest, 3 - middle mountain forest, 4 - mountain valleys with steppes, meadows and semi-aird shurbs, 5 - middle mountain arid forest, shrubs, and steppes, 6 middle mountain dark coniferous forest, 7 - plateau with steppes and meadows, 8 - upper mountain pine and brich forest, 9 - highland subalpine sparse forests and shruby meadows, 10 - high mountain alpine meadows, 11 - high mountain sub-nival.

One of the reasons for the diversity of the region's climate is the high altitudinal range (900$3300 \mathrm{~m}$ a.s.1.). The absolute minimum temperature varies between $-29^{\circ} \mathrm{C}$ and $41^{\circ} \mathrm{C}$, while the absolute maximum temperature is between $34^{\circ} \mathrm{C}$ and $39^{\circ} \mathrm{C}$. Annual precipitation varies between $400 \mathrm{~mm}$ and $1400 \mathrm{~mm}$. There are currently five small cities, seven towns and 259 villages in the region, which are allocated in 71 communities. The village population accounts for $65.94 \%$ of the total population. There are five types of natural landscape, nine subtypes, 15 genera and 120 facets (Maisuradze et al. 2020).

\section{Materials and methods}

In the research presented here, we applied the historical geoinformation system approach, which is also known as Historical GIS, HGIS of HISGIS. The approach implies an application of historic sources and GIS tools to revive certain features of the landscape and make them visible through the maps. HGIS involves several research methods. Scholars from many branches of historical study are turning to geospatial techniques to explore spatial relationships, to reconstruct past places and natural environments (Knowles 2005). The method involves the use of standard sources of data such as censuses, and visualizing them locally and regionally within a GIS environment, to make comparisons across both space and time (Black, MacDonald 2005). The integration of census and geographic data can not only elevate the management of census information but also widen the application of census information in other potential fields. Many countries, no matter the developed or the developing ones, are attaching great importance to the study and implementation of the census GIS (Xinzhou et al. 2001).

Our study is based on a written source compiled in the sixteenth century, known as the Great Defter of Gurjistan Vilayet. Officials of the Ottoman Empire prepared the document after 
they captured the southwestern part of Georgia as a result of a long military campaign (Imber 2002). Based on the primary Ottoman sources, academician Sergi Jikia prepared and published the work in Georgian in two parts in 1941 and 1958 (Jikia 1941, 1958). The source includes information about the territory of the present Samtskhe-Javakheti, and also the areas outside it (Jikia 1941). In the paper, we have also used works from the past centuries, which provide information about the history, culture and settlements. According to Defter, there were more than 700 settlements in the region in the second half of the sixteenth century (Jikia 1958, Svanidze 1967). Their role and status were determined by the location, defence, trade communications and other functions. The centres of the administrative units were mostly fortress Rabats, the rest of the settlement were villages. At that time, the population comprised only a few tens of thousands (Jaoshvili 1984, Lomsadze 1975).

A map of the administrative units of the sixteenth century was first compiled in the twentieth century by Prof. Alexander Aslanikashvili (Aslanikashvili 1953), where the administrative units of Gurjistan Vilayet - Liva and Nahia were delineated, and also the settlements were depicted. We identified the location of the settlements, using the Soviet topographic maps (1:25,000), satellite images (Google Earth images) and the geoinformation system. After, we prepared a database with different thematic content, including information on the architectural types of buildings. The maps presented in the article were compiled using QGIS 3.16.

The field expeditions were organised in 20172018 to study the settlements described in the Great Defter of Gurjistan Vilayet, and comparing them with the current conditions. We photographed the settlements and got acquainted with their architectural features. We also assessed the forms of adaptation to the local landscape, as well as their use in modern times.

\section{Results}

According to the Great Defter of Gurjistan Vilayet by the second half of the sixteenth century, there were 1184 settlements in the entire Vilayet, more than 700 of which were located within the state boundary of modern Georgia. The mapping of the mentioned settlements included identifying their location, preparing a database, and classifying architectural types of buildings. During the sixteenth century, the appearance of the cities was very different from their current states. They were usually characterised by a suburban agricultural zone and a defensive, fortification building. The 22 settlements of the region were Rabat fortresses, which were functionally relevant to the common type of city of the study period. Besides, several settlements were referred to as small towns during this period such as Gokia and Baraleti (Lomsadze 1975). The total number of cities was quite high, considering the population of that time, which indicates that the urban way of life was quite advanced (Jaoshvili 1984).

Several factors were determining the architectural features of the buildings. The first was the need to adapt to environmental conditions (Fig. 2). The semi-underground and hall type Meskhetian Oda dominated the volcanic plateau, where two hypsometric steps were distinguished within the two subtypes of the landscape. The first is a plateau with steppe and meadow vegetation, and the second is a subalpine forest, shrub, meadow landscape (Beruchashvili 1995, Maisuradze et al. 2018). Similar buildings were also spread along the volcanic canyons and in the Meskheti Valley, where, together with stone buildings, they formed a unified architectural style of settlements. Harsh long winters characterise the plateaus of Javakheti and Niala. The overlap with the ground, under which the semi-underground and flat-roofed halls were placed, protected them from the severe winter frosts and helped to retain heat. Less frosty winters and hot summers characterise Tmogvi and Vardzia canyon and Samtskhe Valley. Similar buildings were found in the Kvabliani Valley, as well as on the less forested slopes of the Arsian Range. The relief factor explains the dominance of such buildings in this section. There is one difference, the villages here have terraced structures, half of the houses are placed underground, and the cut land or bare rock is being used as the house wall. Stone buildings were also spread in the valley and the lower belt zone of the mountain to the east. Like the Javakheti plateau, sharp frosts characterised more precipitation in the Kvabliani, Odzrkhe, Gujaratistskali and Borjomula river valleys, the 
Meskheti and Trialeti mountain system, and the Tori, Bakuriani, Mitarbi and Tsemi plateaus. Settlements here are found not only semi-underground but also dominated by wooden $\log$ houses.

In addition to climate adaptability, factors such as the availability of building materials were of great importance. Wood was used everywhere for construction, albeit in different intensities. The wood used in the region was in accordance with the specific rules of its processing. A mixture of warm wax and oil was often used, presumably flax seed oil, which made the Samtskhe-Javakheti region unique. The mixture of wax and oil was used to process the building material, which made the wood more resistant to moisture, disease, fungi and pests (Khoshtaria et al. 2019). For semi-underground houses, wood was also used as a support pole to hold the roof of the compacted land in place. Swallow roofing halls, where wood was more commonly used, are relatively few. For stone houses, wood was used in larger doses, and it was also used in the form of poles, coils, roofs, windows and partitions. Stone buildings are typical of forest landscapes, and as for the Tori, Bakuriani and Mitarbi plateaus and the upper part of the river Kvabliani, as well as the settlements of the Meskheti ridge, there were wooden houses covered with wooden planks (Adamia 1967). These settlements are associated with the spread of boreal ecosystems. Local timber was used as construction material in the area where Caucasian spruce and oriental spruce were widespread.

The fuel materials were unevenly distributed in the study region. Javakheti plateau was almost devoid of forests and firewood. Manure was used as a fuel here (Kaukhchishvili 1973). Firewood was hard to find, but still available in the Samtskhe valley, whereas in the gorges it was easily available. Most of the stone houses were built on the Borjomi and Kvishkheti sections and the slopes of the Meskheti and Trialeti ridges, which were located near the forests, thus firewood was easily accessible. In the Dzindze, Kvabliani, Otskhe gorges, and the Bakuriani, Tori, Mitarbi and Tsikhisjvari sections, wooden planks and logs were predominantly used as building materials. Such buildings were found not only in the forested land but also above the alpine treeline, near the boreal ecosystems. These ecosystems were characterised by high productivity and an abundance of fuel. This turned out to be one of the reasons why wooden houses dominated the area, which still retain their appearance.

The relief factor, along with geological and seismic factors, determined the characteristics of the buildings. The low buildings, which were built on the Javakheti plateau and Erusheti, Tmogvi, Aspindza and Atskuri sections, had a form adapted to seismic events. Tall houses and massive stone or brick buildings were prone to collapse, and the result would have been more deplorable, in case of an earthquake. The devastating earthquakes were frequent in the region. If we take into account the records of the Middle Ages, the earthquakes of 1089 and 1283 were especially strong, which caused considerable damage to Samtskhe-Javakheti (Gaprindashvili 1966, Tatishvili 1970). Earthquakes have been frequent in the recent past. In the twentieth century, devastating tremors were recorded, resulting in casualties and other serious consequences (Gaprindashvili 1966, Berdzenishvili 1988). According to the modern zoning of seismicity, Samtskhe-Javakheti is considered to be a seismically unstable zone (Matcharashvili 2011). Low houses with thick walls weakened the devastating effect of the earthquake. The height of the collapsed walls should have been less than the

Table 1. Sixteenth-century settlements, population and architectural style.

\begin{tabular}{|l|c|c|c|c|}
\hline \multicolumn{1}{|c|}{ Architectural type of building } & $\begin{array}{c}\text { Number of } \\
\text { settlements }\end{array}$ & $\begin{array}{c}\text { The share of } \\
\text { settlements [\%] }\end{array}$ & Population & $\begin{array}{c}\text { The share of the } \\
\text { population [\%] }\end{array}$ \\
\hline Fortress Rabat with stone houses & 22 & 3.8 & 5530 & 13.8 \\
\hline Stone houses & 60 & 10.5 & 2142 & 5.3 \\
\hline Semi-underground houses mixed with stone houses & 192 & 33.5 & 15,071 & 37.6 \\
\hline Semi-underground houses & 214 & 37.3 & 13,741 & 34.3 \\
\hline Terraced semi-underground houses & 47 & 8.2 & 2688 & 6.7 \\
\hline Cave dwellings & 3 & 0.5 & 35 & 0.1 \\
\hline Wooden log houses & 35 & 6.1 & 903 & 2.3 \\
\hline Total & 573 & 100.0 & 40,068 & 100.0 \\
\hline
\end{tabular}


width of the house, which ensured the avoidance of casualties. Swallownest roofing was a specific precaution to protect itself from the effects of the earthquake, as the semidiagonally arranged poles on the roof took over the weight of the roof and reduced the risk of collapse. As for the resilience to exodynamic events, semi-underground houses created a terrace-like structure and were better protected from gravitational processes on the slope. The steep slopes of the Meskheti and Trialeti ridges were dominated by wooden houses adapted to the slope steepness. Settlements in the Bakuriani, Tsemi, Tori and Mitarbi sections have been adapted to seismic activity because wooden houses are less dangerous during earthquakes.

Looking at the types of buildings and the military or political events in the region, one would undoubtedly find a connection between them. People were reluctant to live in the forests due to a lack of arable land. A significant part of the region is deforested or has been cut down since ancient times. During the military interventions here, the settlements would be a good target

Table 2. Landscapes, settlements, population and architectural style.

\begin{tabular}{|c|c|c|c|c|c|}
\hline Landscape & $\begin{array}{c}\text { Architectural } \\
\text { type of building }\end{array}$ & $\begin{array}{l}\text { Number of } \\
\text { settlements }\end{array}$ & $\begin{array}{c}\text { The share of } \\
\text { settlements [\%] }\end{array}$ & Population & $\begin{array}{l}\text { The share of the } \\
\text { population [\%] }\end{array}$ \\
\hline \multirow[t]{2}{*}{ Middle mountain Colchian forest } & $\mathrm{G}$ & & 100.00 & & \\
\hline & Total & 4 & 100.00 & & \\
\hline \multirow[t]{4}{*}{ Lower mountain semihumid forest } & A & 1 & 8.333 & & \\
\hline & B & 9 & 75 & & \\
\hline & C & 2 & 16.67 & 84 & 100.00 \\
\hline & Total & 12 & 100.00 & 84 & 100.00 \\
\hline \multirow[t]{3}{*}{ Middle mountain forest } & B & 2 & 66.67 & & \\
\hline & G & 1 & 33.33 & & \\
\hline & Total & 3 & 100.00 & & \\
\hline \multirow{4}{*}{$\begin{array}{l}\text { Middle mountain arid forests, } \\
\text { shrubs and steppes }\end{array}$} & A & 2 & 4.54 & 1330 & 34.67 \\
\hline & $\mathrm{D}$ & 37 & 84.09 & 2226 & 58.03 \\
\hline & $\mathrm{F}$ & 3 & 6.82 & 77 & 2.01 \\
\hline & Total & 45 & 100.00 & 3836 & 100.00 \\
\hline \multirow{6}{*}{$\begin{array}{l}\text { Mountain valleys with steppes, } \\
\text { meadows and semiarid shrubs }\end{array}$} & A & 8 & 4.49 & 3773 & 21.41 \\
\hline & $\mathrm{B}$ & 12 & 6.74 & 798 & 4.53 \\
\hline & $\mathrm{C}$ & 146 & 81.02 & 11,977 & 67.98 \\
\hline & $\mathrm{D}$ & 10 & 5.62 & 917 & 5.2 \\
\hline & $\mathrm{E}$ & 2 & 1.12 & 154 & 0.87 \\
\hline & Total & 178 & 100.00 & 17,619 & 100.00 \\
\hline \multirow[t]{4}{*}{ Plateau with steppes and meadows } & A & 1 & 0.87 & 21 & 0.25 \\
\hline & C & 2 & 1.74 & 273 & 3.28 \\
\hline & $\mathrm{D}$ & 112 & 97.39 & 8022 & 96.46 \\
\hline & Total & 115 & 100.00 & 8316 & 100.00 \\
\hline \multirow{6}{*}{$\begin{array}{l}\text { Middle mountain dark coniferous } \\
\text { forest }\end{array}$} & A & 8 & 6.35 & 343 & 5.3 \\
\hline & $\mathrm{B}$ & 36 & 28.57 & 1344 & 20.76 \\
\hline & C & 39 & 30.95 & 2562 & 39.57 \\
\hline & $E$ & 14 & 11.11 & 1281 & 19.78 \\
\hline & $G$ & 29 & 23.02 & 945 & 14.59 \\
\hline & Total & 126 & 100.00 & 6475 & 100.00 \\
\hline \multirow{4}{*}{$\begin{array}{l}\text { Upper mountain pine and birch } \\
\text { forest }\end{array}$} & A & 2 & 25 & 63 & 64.29 \\
\hline & $C$ & 1 & 12.5 & & \\
\hline & $E$ & 4 & 50 & 35 & 35.71 \\
\hline & Total & 8 & 100.00 & 98 & 100.00 \\
\hline \multirow{3}{*}{$\begin{array}{l}\text { Highland subalpine sparse forests } \\
\text { and shrubby meadows }\end{array}$} & C & 53 & 67.09 & 2506 & 70.2 \\
\hline & $E$ & 26 & 32.91 & 1064 & 29.8 \\
\hline & Total & 79 & 100.00 & 3570 & 100.00 \\
\hline
\end{tabular}

A - Fortress Rabat with stone houses, B - Stone houses, C - Semi-underground houses mixed with stone houses, D - Semi-underground houses, E - Terraced semi-underground houses, F - Cave dwellings, G - Wooden log houses. 

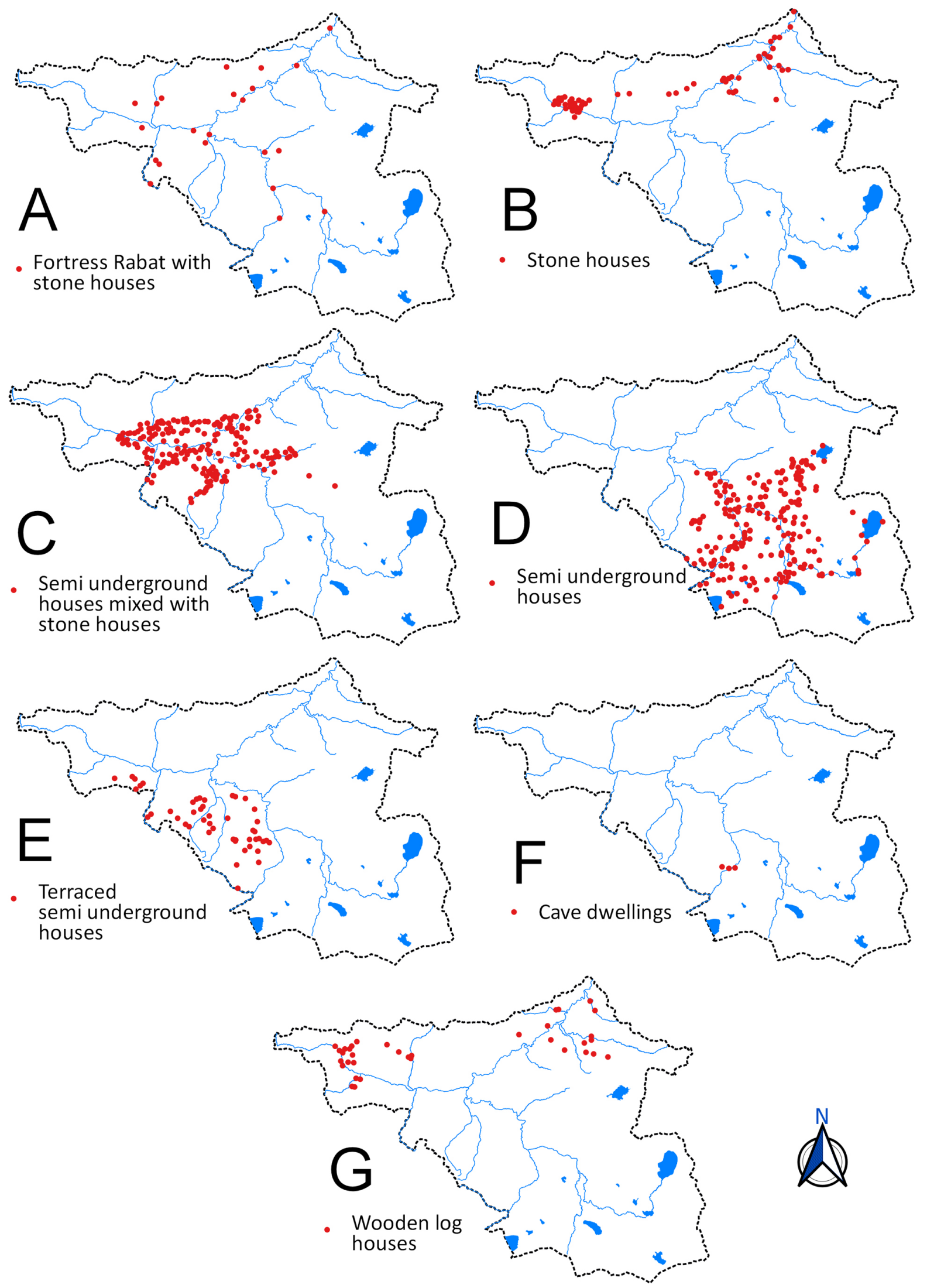

Fig. 3. The geographical allocation of the folk architecture.

A - Fortress Rabat with stone houses, B - Stone houses, C - Semi-underground houses mixed with stone houses, D Semi-underground houses, E - Terraced semi-underground houses, F - Cave dwellings, G - Wooden log houses. 

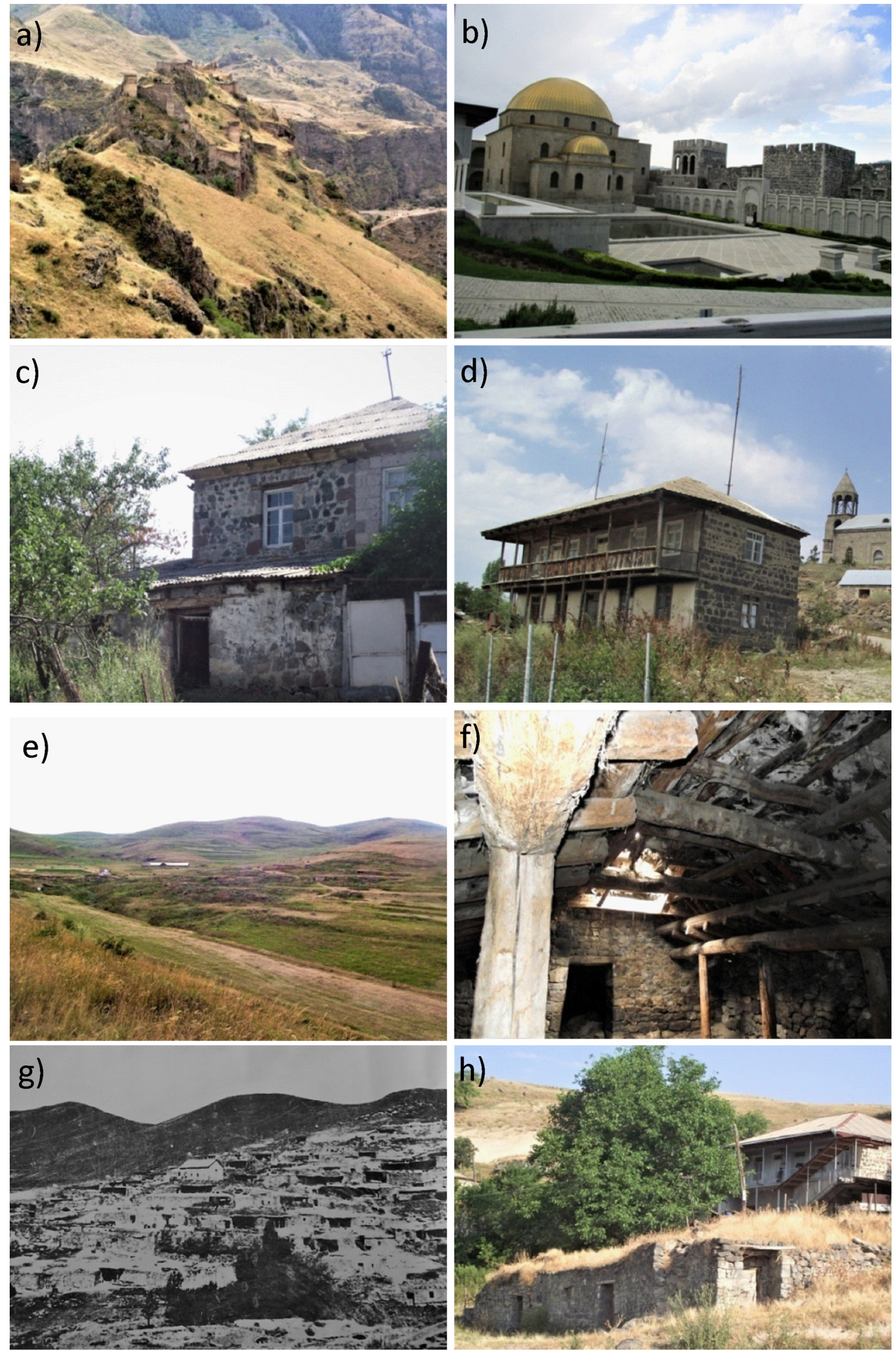

Fig. 4. Architectural types of buildings from Samtskhe-Javakheti.

A - Tmogvi Castel - fortress Rabat with stone houses, B - Akhaltsikhe Rabat - fortress Rabat with stone houses, C Village Muskhi - stone houses, D - Village Khizabavra - stone houses, E - Village Zeda Tmogvi - semi-underground houses, F - Village Zeda Tmogvi - the interior of the semi-underground house, G - Village Chobareti - terraced semi-underground houses (from Zedginidze family archive from village Chobareti, the 1920s), H - Village Chobareti - modern condition of the terraced semi-underground houses. (Photo by R. Maisuradze, 2017-2018). 
for the enemy. This is why most of the villages on the plateau have been built on the edge of rocky canyons. Semi-underground houses were characterised by the so-called Darans, an underground tunnel stone building. Ground grass roofing fulfils the role of camouflage. The village of Zeda Tmogvi is the best example of such camouflage, and other settlements have taken a similar look for this reason. In the Vardzia, Tmogvi and Aspindza sections, the rocks served as a kind of natural camouflage, and the volcanic caves located here were also significant in the context of defence.

The situation was different in the Samtskhe Valley, where the villages were built in a sheltered place on the mountain. On the slopes of the Meskheti and Arsiani mountains, the Trialeti ridge and the Borjomi, Bakuriani, Tori, Mitarbi and Tsikhisjvari plateaus, a stable forest cover served as a way to hide from the enemy. Therefore, the settlements here no longer needed additional camouflage (Ochiauri 1970, Tatishvili 1970).

In the second half of the sixteenth century, the rural and urban settlements in the region differed from each other in their architectural appearance.
In the research, we identified the area of their distribution. We classified the settlements marked on the map according to their unique architectural types (Tables 1, 2). On the map, we represented seven architectural types of buildings that were characteristic of medieval settlements (Fig. 3).

Following architectural types of buildings are found in Samtskhe-Javakheti (Figs. 4, 5).

Fortress Rabat with stone houses. This type of settlement was characterised by external and internal fences, defensive fortifications, commercial and religious buildings, mixed architectural type houses, including two and three-storeyed. Such settlements were found in various parts of the region, namely, in Samtskhe Valley, Mtkvari Canyon, volcanic plateaus, and river gorges.

Stone houses. This type of settlement was characterised by single or rarely two-storey buildings, which were spread in the western part of the Samtskhe Valley, on the foothills, in the Okrostsikhe, Odzrkhe and Fesleti section, in the Borjomi Gorge, on the Borjomi-BakurianiTsikhisjvari plateaus.

Semi underground houses mixed with stone houses. These are a mixed type of semi-under-
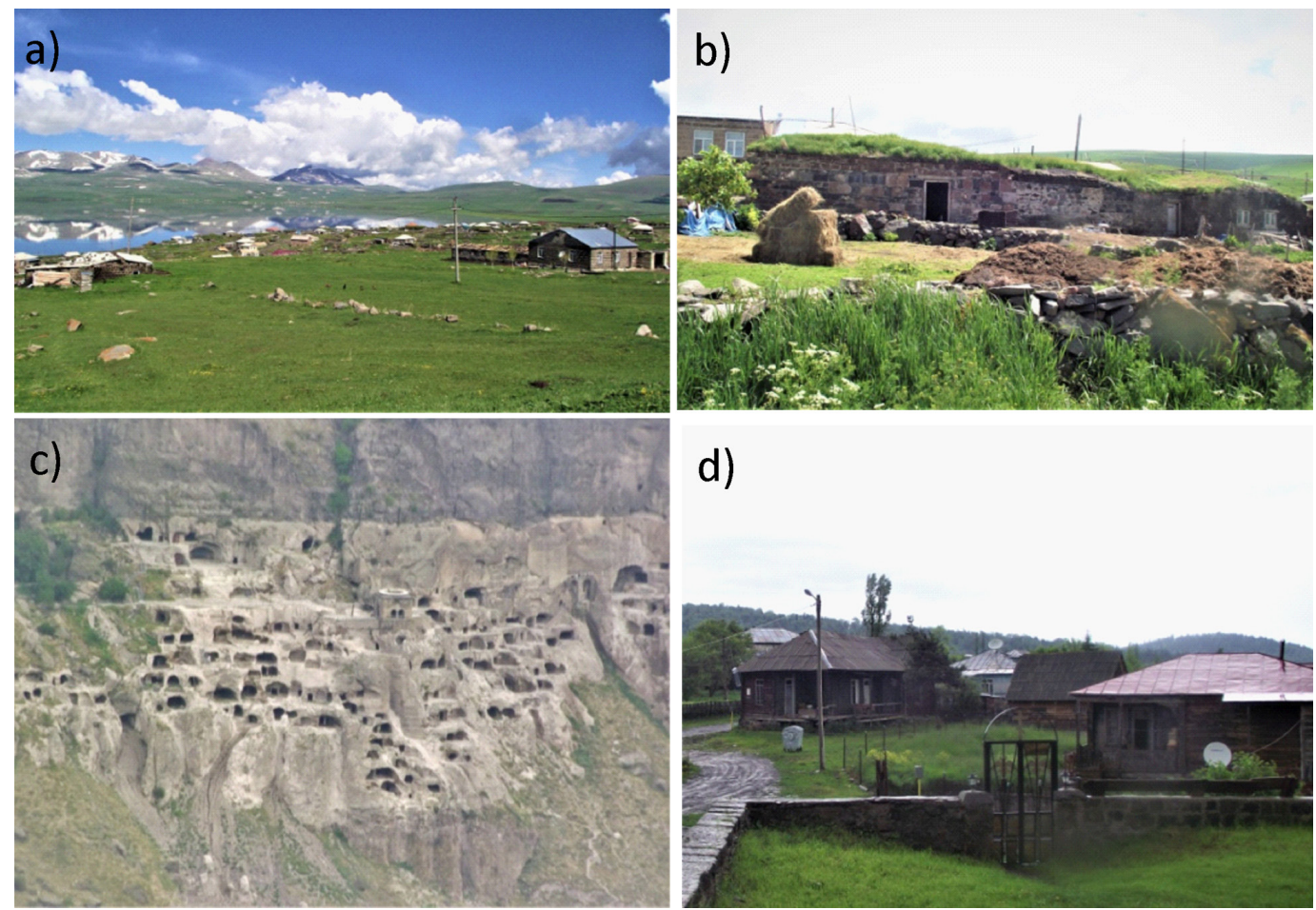

d)

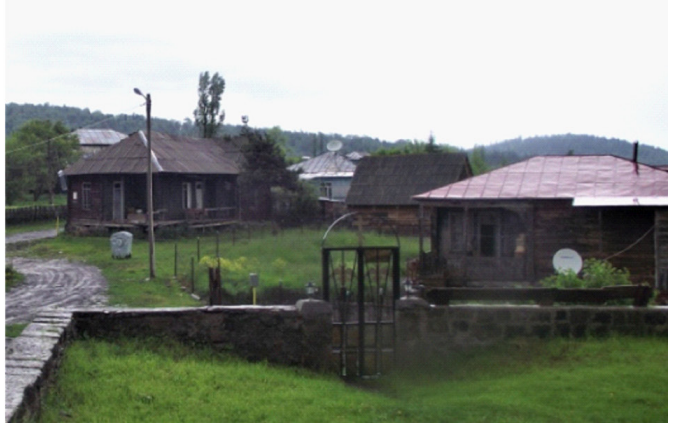

Fig. 5. Architectural types of buildings from Samtskhe-Javakheti.

A - Village Faravana - semi-underground houses mixed with stone houses, B - Village Saghamo - the modern condition of the semi-underground houses mixed with stone houses, C - Cave city Vardzia - Cave dwellings, D - Village Tsikhisdjvari - wooden log houses. (Photo by R. Maisuradze, 2017-2018). 
ground and stone one and two storey houses, which was spread in the Samtskhe cave, in the Atskuri, Slesa and Tsinubani sections.

Semi underground houses. These types were characterised by partially underground houses and sometimes hall-like, swallow nest-like roofs. Such settlements were spread in the Javakheti Plateau, Aspindza, Tmogvi and Vardzia Canyon.

Terraced semi-underground houses. These types extended to the Erusheti Mountains and the Uraveli and Chacharaki sections. They also extended to the Arsian ridge, a subalpine belt where the natural boundary of the forest was often altitudinally drawn below.

Cave dwellings. This category includes residential and religious spaces arranged in volcanic caves, mostly in the Vardzia and Tmogvi canyon.

Wooden log houses. This type was distinguished by one and two-storey houses, spread on the river banks of Kvabliani, Dzindzura, Odzrkhe, Nedzvi, Gujaratistskali, Borjomula and the Borjomi, Bakuriani, Tori, Tsikhisjvari and Mitarbi plateaus.

A comparison of the architectural and settlement types of the sixteenth century to the present shows that significant changes have taken place. On the one hand, the changes have improved housing and sanitation, such as the domestic water supply and sewage system, the electricity supply, the penetration of sunlight, and better ventilation. On the other hand, there has been a tendency to weaken folk buildings, construction traditions and their adaptation to nature. This was followed by the loss of the land fund, homogenisation of the building techniques and architectural forms. Currently, only some settlements are preserved, where houses of a centuries-old style have been preserved. This is especially true for Fortress Rabat, Semi underground, stone and terraced semi-underground houses, which require special attention and recovery. Such settlements are collapsing and difficult to predict how they will look in the face of current trends.

\section{Conclusions}

Five main factors determined the architectural diversity of Samtskhe-Javakheti settlements: a need to adapt to the environment, building material availability, fuel availability, relief and seismic factors, military and defence factors and need for camouflage. There were seven main types of buildings in the region: Fortress Rabat, Stone houses, Semi underground houses mixed with stone houses, semi-underground, terraced semi-underground houses, Cave dwellings and Wooden log houses. Each type of construction was related to specific landscape taxonomic units, which led to the dominance of a particular architectural type. Centuries-old architectural diversity began to disappear in the mid-twentieth century. This trend is linked to the gradual forgetting of the construction tradition and the strengthening of the role of planned constructions. Since the middle of the twentieth century, villages have grown at the expense of arable land. This changes the appearance of settlements and leads to the disappearance and replacement of cultural heritage with uniform buildings.

\section{Acknowledgments}

This research was supported by the Shota Rustaveli National Science Foundation of Georgia (SRNSFG) [grant number YS-2016-44]. We are grateful to two anonymous reviewers.

\section{Author's contribution}

Conceptualization: RM, TKh; Data collection: RM, TE, TKh; Data analysis and interpretation: RM, TKh, TE; Manuscript writing and revision: RM, TKh, TE.

\section{References}

Adamia I., 1967. Qartuli satskhovrebeli sakhlebis udzvelesi tipebi acharashi (The oldest types of Georgian houses in Adjara). Monument's Friend 12: 3-12.

Aslanikashvili A., 1953. Gurjistanis vilaietis ruka (Map of the Gurjistan Vilayet). Georgian SSR Academy of Sciences, Institute of Linguistics, Tbilisi.

Battaini-Dragoni G., 2008. The rural vernacular habitat, a heritage in our landscape. Futuropa, for a new vision of landscape and territory 1: 3 .

Berdzenishvili D., 1988. Vardzia da tmogviscixe-qveyana (Vardzian and Tmogviland). Monument's Friend 2: 46-54.

Beruchashvili N., 1995. Kavkaz: landshafti, modeli, eksperimenti (The Caucasus: Landscapes, Models, Experiments). Tbilisi State University Press, Tbilisi.

Black F.A., MacDonald B.H., 2005. HGIS of print culture in Canada. Historical Geography 33: 154-156.

Braudel F., Wallerstein I., 2009. History and the social sciences: The Longue Durée. Review (Fernand Braudel Center) 32(2): 171-203.

Charter A., 1931. The Athens Charter for the restoration of historic monuments. Adopted at the First International Con- 
gress of Architects and Technicians of Historic Monuments, Athens.

Charter V., 1964. International charter for the conservation and restoration of monuments and sites. Venice, Italy.

Cirucci J.F., Miller D.A., Blanford J.I., 2015. Retrospective GIS-based multi-criteria decision analysis: A case study of California waste transfer station siting decisions. In: International Symposium on Sustainable Systems and Technology. Dearborn: 18-20. DOI 10.6084/M9. FIGSHARE.1512514.

Gaprindashvili G., 1966. Tmogvi (Tmogvi). Monument's Friend 8: 41-46.

Gregory I.N., Healey R.G., 2007. Historical GIS: Structuring, mapping and analysing geographies of the past. Progress in Human Geography 31(5): 638-653. DOI 10.1177/0309132507081495.

Ilies N.M., Moldovan I.M., 2014. Underground houses on sliding slopes. Acta Technica Napocensis: Civil Engineering \& Architecture 57(2): 139-148.

Imber C., 2002. The Ottoman Empire, 1300-1650: The structure of power. Red Globe Press, London.

Jaoshvili V., 1984. Saqartvelos mosaxleoba XVIII-XX saukuneebshi (Population of Georgia in the XVIII-XX centuries). Metsniereba, Tbilisi.

Jibson R.W., 2011. Methods for assessing the stability of slopes during earthquakes - A retrospective. Engineering Geology 122(1-2): 43-50. DOI 10.1016/j.enggeo.2010.09.017.

Jikia S., 1941. Gurjistanis vilaietis didi davtari, nawili II (Great Defter of Gurjistan Vilayet, part II). Publishing House of the Georgian Academy of Sciences of Soviet Republic of Georgia, Tbilisi.

Jikia S., 1958. Gurjistanis vilaietis didi davtari, nawili III (Great Defter of Gurjistan Vilayet, part III). Publishing House of the Georgian Academy of Sciences of Soviet Republic of Georgia, Tbilisi.

Kaukhchishvili S. (ed.), 1973. Life of Kartli, Volume IV. Tbilisi.

Khoshtaria T., Chachava N., Vardosanidze V., Tsilosani Sh., 2019. Main factors of spatial landscape planning in Samtskhe-Javakheti region. In: The International Multidisciplinary Conference Actual Problems of Landscape Sciences: Environment, Society, Politics. Tbilisi: 9-13.
Knowles A.K., 2005. Emerging trends in historical GIS. Historical Geography 33: 7-13.

Lomsadze Sh., 1975. Samtskhe-javakheti XVIII saukunis shua tslebidan XIX saukunis shua tslebamde (Samtskhe-Javakheti: from the middle of XVIII to middle of XIX centuries). Metsniereba, Tbilisi.

Maisuradze R., Elizbarashvili M., Khardziani T., Tatishvili M., 2018. Landscapes of Samtskhe-Javakheti region, transformation degree and forms. International Multidisciplinary Scientific GeoConference: SGEM: Surveying Geology \& mining Ecology Management 18: 487-494. DOI 10.5593/sgem2018/5.1/S20.063.

Maisuradze R., Khardziani T., Eradze T., 2020. Retrospective mapping of the XVI century Samtskhe-Javakheti viticulture and fruit farming. Miscellanea Geographica 24(1): 5-15. DOI 10.2478/mgrsd-2019-0027.

Matcharashvili T., Chelidze T., Javakhishvili Z., Jorjiashvili N., Paleo U.F., 2011. Non-extensive statistical analysis of seismicity in the area of Javakheti, Georgia. Computers $\mathcal{E}$ Geosciences 37(10): 1627-1632. DOI 10.1016/j.cageo.2010.12.008.

Ochiauri T., 1970. Gardamavali tipis nagebobebi zemo da qvemo qartlshi (Transitional types of buildings in Zemo and Kvemo Kartli). Monument's Friend 20: 28-30.

Sangiorgi F., 2008. The vernacular rural heritage: From the past to the future. Futuropa 1: 4-5.

Svanidze M., 1967. Samcxe-saatabagos administraciuli dakofa da socialuri mdgomareoba gurjistanis vilaietis didi davtris mixedvit (An administrative division of the Samtskhe-Saatabago and social situation according to the Great Defter of Gurjistan Vilayet). TSU Works 121: 291-308.

Tatishvili T., 1970. Mitsisqvesha nagebobani mtkvris zemo tselze (Underground buildings in the upper reaches of the Mtkvari). Monument's Friend 21: 18-22.

Vallerani M., 1995. Urban decay and abandonment in western medieval Sicily: A problem for the study of strong earthquakes. Annals of Geophysics 38(5-6): 691-703.

Xinzhou W., Zongwei L., Shunqing C., 2001. Some issues on urban census GIS designing. Geo-spatial Information Science 4(4): 25-31. 